\title{
INISIASI POSYANDU REMAJA MELALUI PEMBENTUKAN DUTA COVID-19
}

\author{
Siti Rofi'ah 1)*; Sri Widatiningsih²; Fadhilah Rahayu33; Egha Wahyu Fatikasari'; Riska \\ Dwi Krismawati5; Deshinta Nuke Rimanury6; Miranda Agustina7
}

\author{
1, 2, 3, 4, 5, 6, 7 Prodi Kebidanan Magelang ; Poltekkes Kemenkes Semarang \\ Jl. Perintis Kemerdekaan, Kota Magelang
}

\begin{abstract}
Abstrak
Pembentukan Posyandu Remaja diharapkan menjadi wadah untuk memfasilitasi remaja dalam memahami permasalahan kesehatan remaja, menemukan alternatif pemecahan masalah, membentuk kelompok dukungan remaja, memperluas jangkauan Puskesmas PKPR. Pada masa pandemi Covid-19 ini, sangat tepat apabila remaja dilibatkan dalam upaya memutus rantai penularan Covid-19. Kegiatan Pengabmas ini bertujuan untuk menginisiasi kegiatan Posyandu Remaja dengan membentuk Duta Covid-19. Metode yang digunakan adalah membentuk Posyandu Remaja "Cerdik" serta melakukan pemberdayaan remaja sebagai kader posyandu Remaja sekaligus sebagai Duta Covid-19 melalui kegiatan pelatihan dan pendampingan. Hasil kegiatan berupa Posyandu Remaja “CERDIK" dan Kader Posyandu Remaja sekaligus Duta Covid-19, Modul Posyandu Remaja dan Modul Covid-19 yang telah memperoleh sertifikat Hak Cipta serta terjalin kerjasama antara Poltekkes Kemenkes Semarang dengan Pemerintah Desa Bojong sebagai Mitra PUI P2PTM “Desa Sehat Remaja Bebas Anemia Defisiensi Fe". Kader posyandu mengalami peningkatan tingkat pengetahuan sebanyak $77 \%$. Kader mampu melakukan pengukuran suhu, cara mencuci tangan dan pemakaian masker yang benar, cara membuat larutan desinfektan dan melakukan proses desinfeksi.
\end{abstract}

Kata kunci: Inisiasi, Posyandu Remaja; Duta Covid-19

\begin{abstract}
[INITIATION OF YOUTH POSYANDU THROUGH THE ESTABLISHMENT COVID-19 AMBASSADOR] It is hoped that the establishment of the Youth Posyandu can become a forum to facilitate adolescents in understanding adolescent health problems, find alternative solutions to problems, form youth support groups, expand the reach of the PKPR Puskesmas. During the Covid-19 pandemic, it is very appropriate for teenagers to be involved in efforts to break the chain of Covid-19 transmission. This Community Service activity aims to initiate Youth Posyandu activities by forming Covid-19 Ambassadors. The method used was to form "Cerdik" Youth Posyandu and to empower youth as youth Posyandu cadres as well as Covid-19 Ambassadors through training and mentoring activities. The results of activities in the form of "CERDIK" Youth Posyandu and Youth Posyandu Cadres as well as Covid-19 Ambassadors, Youth Posyandu Module and Covid-19 Module which have obtained IPR certificates and a collaboration between the Poltekkes Ministry of Health Semarang and the Bojong Village Government as PUI P2PTM Partners "Youth Healthy Village Free from Fe Deficiency Anemia". Posyandu cadres experienced an increase in the level of knowledge as much as $77 \%$. Cadres were able to take temperature measurements, how to wash hands and use masks correctly, how to make disinfectant solutions and carry out the disinfection process.
\end{abstract}

Keywords: Initiation, Youth Posyandu; Covid-19 Ambassadors

\section{Pendahuluan}

Masa remaja merupakan masa storm and stress, pada masa ini remaja mengalami banyak

*) Correspondence Author (Siti Rofi'ah)

E-mail: nandasheeta@yahoo.com tantangan baik dari diri mereka sendiri (biopsychosocial factors) maupun dari lingkungan (environmental factors). Pada masa ini, apabila seorang remaja tidak memiliki kemampuan untuk menghadapi berbagai tantangan tersebut maka dapat berakhir pada berbagai masalah 
kesehatan yang begitu kompleks. Permasalahan tersebut muncul sebagai akibat dari perilaku berisiko yang dilakukan oleh remaja (Kementerian Kesehatan Republik Indonesia, 2018)

Permasalahan kesehatan pada remaja yang cukup kompleks membutuhkan penanganan yang komprehensif dan terintegrasi yang melibatkan semua unsur dari lintas program dan sektor terkait. Kebijakan bidang kesehatan terkait pelayanan kesehatan remaja sebagaimana dimaksud Permenkes Nomor 25 Tahun 2014 ditujukan agar setiap anak memiliki kemampuan berperilaku hidup bersih dan sehat, memiliki keterampilan hidup sehat, dan ketrampilan sosial yang baik sehingga dapat belajar, tumbuh dan berkembang secara harmonis dan optimal menjadi sumber daya manusia yang berkualitas. (Menkes RI, 2014). Upaya pemeliharaan kesehatan remaja seperti yang termuat dalam Undang-undang tentang kesehatan Pasal 136 adalah untuk mempersiapkan menjadi orang dewasa yang sehat dan produktif baik sosial maupun ekonomi termasuk untuk reproduksi remaja dilakukan agar terbebas dari berbagai gangguan kesehatan yang dapat menghambat kemampuan menjalani kehidupan reproduksi secara sehat (Yulika, 2019)

Posyandu remaja merupakan salah satu bentuk Upaya Kesehatan Bersumber Daya Masyarakat (UKBM) yang dikelola dan diselenggarakan dari, oleh, untuk dan bersama masyarakat termasuk remaja dalam penyelenggaraan pembangunan kesehatan, guna memberdayakan masyarakat dan memberikan kemudahan dalam memperoleh pelayanan kesehatan bagi remaja untuk meningkatkan derajat kesehatan dan keterampilan hidup sehat remaja. Pembentukan Posyandu Remaja diharapkan dapat menjadi wadah untuk memfasilitasi remaja dalam memahami permasalahan kesehatan remaja, menemukan alternatif pemecahan masalah, membentuk kelompok dukungan remaja, memperluas jangkauan Puskesmas PKPR, terutama bagi remaja daerah yang memiliki keterbatasan akses (Kementerian Kesehatan Republik Indonesia, 2018).

Keberadaan posyandu remaja sangat tepat sebagai sarana untuk mempersiapkan remaja yang berkualitas sebagai generasi penerus bangsa. Kegiatan pengabdian masyarakat serupa telah dilakukan oleh (Putri and Rosida, 2017) maupun (Ismarwati and Ernawati, 2016). Kehadiran posyandu remaja di tengah masyarakat dapat membantu remaja mengenal kesehatan reproduksi lebih dini sebagai upaya preventif, promotif sehingga dapat mencegah remaja terjerumus dalam pergaulan bebas (Ismarwati and Ernawati, 2016). Manfaat posyandu bagi masyarakat adalah kemudahan mendapatkan pelayanan kesehatan dasar, memperoleh bantuan dalam pemecahan maalah kesehatan, efisiensi dalam mendapatkan pelayanan terpadu (Susanti, Apriasih and Danefy, 2020)

Pelayanan kesehatan remaja di Posyandu adalah pelayanan kesehatan yang peduli remaja, mencakup upaya promotif dan preventif, meliputi: Ketrampilan Hidup Sehat (PKHS), kesehatan reproduksi remaja, kesehatan jiwa dan pencegahan penyalahgunaan Napza, gizi, aktifitas fisik, pencegahan Penyakit Tidak Menular (PTM) dan pencegahan kekerasan pada remaja (Kementerian Kesehatan Republik Indonesia, 2018). Sesuai pelayanan kesehatan tersebut, maka pada era Covid-19 ini sangat tepat apabila remaja dilibatkan dalam upaya menekan angka penularan virus ini. Remaja sebagai pribadi yang aktif dan kreatif serta memiliki rasa ingin tahu yang tinggi dapat menjadi suatu kekuatan dalam meningkatkan kualitas kesehatan masyarakat. Selain bagi kepentingan remaja sendiri, sikap remaja yang selalu ingin berinovasi dapat dimanfaatkan pada kegiatankegiatan yang positif. Remaja tidak hanya cukup berpangku tangan namun dituntut mampu memberikan sumbangsih tenaga maupun fikiran dalam menekan penyebaran wabah ini.

Hasil penelitian (Sukini, Widatiningsih and Rofi'ah, 2017) menyarankan agar dalam meningkatkan pengetahuan kesehatan reproduksi remaja maka diutamakan melalui dukungan teman sebaya. Hal ini menunjukkan bahwa peran remaja dalam mengajak serta memberikan dukungan terhadap sebaya dalam melakukan perilaku positif akan memberikan hasil yang cukup baik. Keterlibatan remaja dalam masa pandemi Covid-19 ini salah satunya dengan membentuk "Duta Covid-19". Duta Covid-19 merupakan istilah bagi remaja yang secara sukarela bersedia menjadi bagian dari kader kesehatan khususnya dalam pencegahan penularan virus Covid-19. Kader kesehatan remaja yang dimaksud adalah remaja yang dipilih/secara sukarela mengajukan diri dan dilatih untuk ikut melaksanakan upaya pelayanan kesehatan remaja bagi diri sendiri, teman sebaya, keluarga, serta masyarakat (Kementerian Kesehatan Republik Indonesia, 2018).

Covid-19 dinyatakan sebagai pandemi 
dunia oleh WHO dan ditetapkan pemerintah sebagai bencana non alam berupa wabah penyakit yang perlu dilakukan langkah-langkah penanggulangan terpadu termasuk keterlibatan seluruh komponen masyarakat (Kementerian Kesehatan Republik Indonesia, 2020). Poltekkes Kemenkes Semarang sebagai salah satu institusi pendidikan kesehatan di Jawa Tengah merasa memiliki tanggungjawab untuk ikut terlibat dalam penanggulangan wabah Covid-19. Salah satu program studi yaitu Prodi Kebidanan Magelang berada di zona merah pandemi Covid19. Oleh karena itu, Prodi dalam hal ini Dosen dan Mahasiswa perlu melakukan aksi nyata dalam memutus rantai penularan virus corona. Desa Bojong kecamatan Mungkid kabupaten Magelang menjadi pilihan lokasi kegiatan pengabdian masyarakat dalam membentuk "Duta Covid-19" sebagai inisiasi Posyandu Remaja.

\section{Metode Pelaksanaan}

Kegiatan Pengabdian Masyarakat “Inisiasi Posyandu Remaja melalui Pembentukan Duta Covid-19" telah dilakukan melalui tahapan persiapan, pelaksanaan dan evaluasi. Tahap persiapan kegiatan dengan melakukan koordinasi tim pelaksana serta koordinasi dengan Bidan Desa dan Kepala Desa Bojong untuk membentuk kader posyandu remaja dan menginisiasi posyandu remaja serta menentukan sasaran dan model pelaksanaan kegiatan. Tim pengabdi mengajukan permohonan ijin ke Kesbangpol Kabupaten Magelang selanjutnya ke DPMPTSP dan Bappeda kabupaten Magelang diteruskan ke Puskesmas Mungkid dan Kecamatan Mungkid serta Pemerintah Desa Bojong Kecamatan MungkidPersiapan materi dan media meliputi modul Posyandu Remaja dan modul Covid-19 untuk kader posyandu.

Adapun metode yang digunakan adalah metode ceramah, demonstrasi dan praktik. Metode ceramah dilakukan untuk memberikan pendidikan kesehatan pada Duta Covid-19 terkait Pandemi Covid-19 dan Kesehatan Remaja, metode demonstrasi dilakukan pada saat memberikan pemahaman tentang cara melakukan pencegahan penularan Covid-19 dan pemantauan kelompok resiko serta cara melaksanakan pelayanan saat kegiatan posyandu remaja. Metode praktik diterapkan saat kader posyandu remaja selaku Duta Covid-19 mempraktikkan cara melakukan pencegahan penularan Covid-19 dan pemantauan kelompok resiko serta cara melaksanakan posyandu remaja.
Tim pengabdian masyarakat melakukan pelatihan dan mendampingi 30 (tiga puluh) orang remaja sebanyak 5 kali pertemuan baik secara teori maupun praktik. Pada pertemuan awal mereka dilakukan pre test selanjutnya diberikan materi berupa teori Covid-19 sebanyak 2 kali pertemuan, materi tentang posyandu remaja sebanyak 1 kali pertemuan. Materi praktik dilakukan dengan demonstrasi dan re demonstrasi melakukan pendampingan secara berkelompok sebanyak 2 kali pertemuan masingmasing untuk materi Covid-19 dan materi Posyandu Remaja. Pada pertemuan terakhir remaja diberikan post test dan memberikan umpan balik kegiatan pembentukan Duta Covid19.

Kegiatan pengabdian masyarakat ini diakhiri dengan analisa hasil pre test dan post test oleh mahasiswa dengan pendampingan Dosen dan penyusunan laporan akhir kegiatan pengabdian masyarakat. Tim pengabdi juga melakukan evaluasi kegiatan dengan melakukan monitoring kegiatan Duta Covid-19 dan keberlangsungan kegiatan Posyandu Remaja mengadakan kunjungan secara rutin setiap bulan dan/ atau melakukan pemantauan melalui bidan desa setempat

Luaran yang dihasilkan dari kegiatan Pengabdian Masyarakat ini adalah Posyandu Remaja "CERDIK" dan Kader Posyandu Remaja sekaligus Duta Covid-19, Modul Posyandu Remaja dan Modul Covid-19 yang telah memperoleh sertifikat pencatatan ciptaan serta terjalin kerjasama antara Poltekkes Kemenkes Semarang dengan Pemerintah Desa Bojong sebagai Mitra PUI P2PTM “Desa Sehat Remaja Bebas Anemia Defisiensi $\mathrm{Fe}^{\text {". }}$. Hasil kegiatan Pengabdian Masyarakat yang diperoleh berupa data deskriptif hasil monitoring evaluasi yang diverifikasi dan disajikan dalam bentuk narasi.

\section{Hasil dan Pembahasan}

\section{Kader Posyandu Remaja Sebagai “Duta Covid- 19"}

Kader Posyandu Remaja merupakan bagian dari Kader Kesehatan Remaja. Kriteria menjadi kader posyandu remaja adalah remaja usia 10-18 tahun, berjiwa kreatif, inovatif dan komitmen, bersedia secara sukarela menjadi kader dan berdomisili di wilayah Posyandu Remaja berada. Kader Posyandu Remaja yang sudah tidak lagi berusia remaja juga dapat tetap bergabung dalam kegiatan Posyandu Remaja. Kader Posyandu Remaja juga dapat bergabung dengan organisasi remaja lainnya seperti Saka Bakti Husada/ saka 
lainnya dalam gerakan pramuka, Karang Taruna atau organisasi yang lain (Kementerian Kesehatan Republik Indonesia, 2018).

Pada kegiatan pengabdian masyarakat ini kader posyandu remaja sekaligus menjadi “Duta Covid-19" akan berperan dalam membantu masyarakat khususnya remaja untuk memutus rantai penularan virus corona. Kader posyandu remaja desa Bojong sebanyak 30 orang mewakili 14 dusun. Masing masing dusun mewakilkan 2 orang remaja yang akan menjadi koordinator sekaligus penggerak remaja di masing-masing dusun, sedangkan 2 orang lainnya sebagai koordinator tingkat desa sebagai ketua dan wakil.

Kader posyandu remaja sekaligus "Duta Covid-19" mendapatkan pelatihan sebanyak 5 kali pertemuan baik secara teori maupun praktik. Pada pertemuan awal mereka dilakukan pre test selanjutnya diberikan materi berupa teori Covid19 sebanyak 2 kali pertemuan, materi tentang posyandu remaja sebanyak 1 kali pertemuan. Materi praktik dilakukan dengan demonstrasi dan re demonstrasi melakukan pendampingan secara berkelompok sebanyak 2 kali pertemuan masing-masing untuk materi Covid-19 dan materi Posyandu Remaja. Pada pertemuan terakhir remaja diberikan post test dan memberikan umpan balik kegiatan pembentukan Duta Covid-19.

Menurut (Susanti, Apriasih and Danefy, 2020) Pelatihan kader remaja mampu meningkatkan pengetahuan kader posyandu remaja. Hal ini terbukti pada kegiatan pengabdian masyarakat ini yaitu berdasarkan hasil analisa tingkat pengetahuan kader posyandu remaja tentang posyandu remaja maupun Covid-19 antara sebelum dan sesudah kegiatan pengabdian masyarakat $(p=0.003)$, pengetahuan Covid-19 para remaja meningkat secara signifikan $(p=0.000)$.

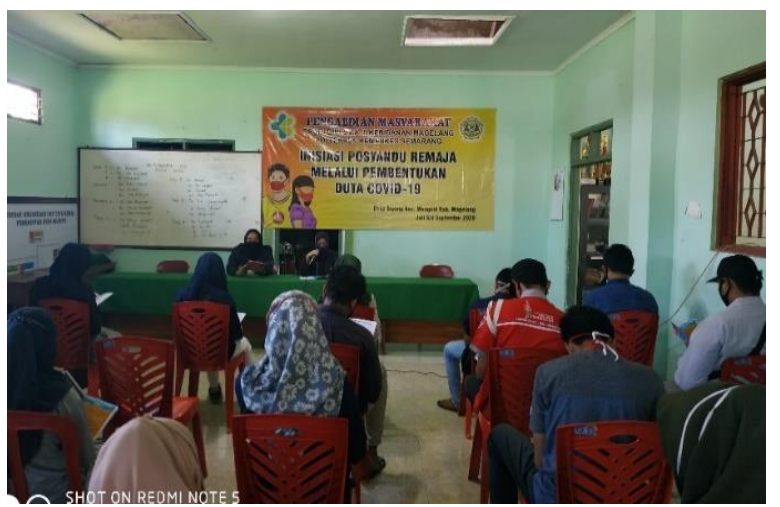

Gambar 1. Kegiatan CTJ tentang Posyandu Remaja
Gambar 1. menunjukkan kegiatan ceramah tanya jawab tentang Posyandu Remaja. Tingkat pengetahuan tentang posyandu remaja meliputi definisi remaja dan posyandu remaja, kegiatan dan pelayanan posyandu remaja, sasaran, tujuan, manfaat, serta tentang KMS Remaja. Sejumlah 18 orang kader posyandu mengalami peningkatan tingkat pengetahuan, 7 orang tetap dan hanya 5 orang yang mengalami penurunan tingkat pengetahuan.

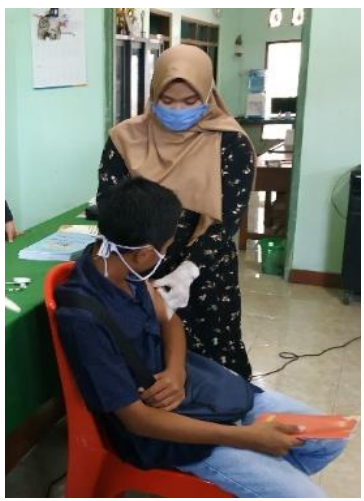

a

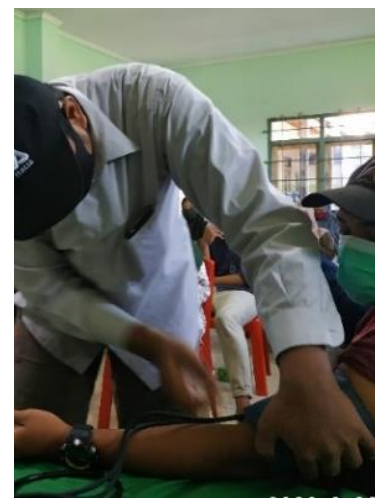

b
Gambar 2. a. Praktik Pengukuran Lingkar Lengan Atas; b. Pengukuran Tekanan Darah oleh Kader Posyandu Remaja

Secara ketrampilan kader mampu melakukan praktik pengukuran tinggi badan, berat badan, lingkar lengan (gambar 2.a), lingkar perut dan tekanan darah (gambar 2.b). Kader juga telah mampu melakukan dokumentasi kegiatan.

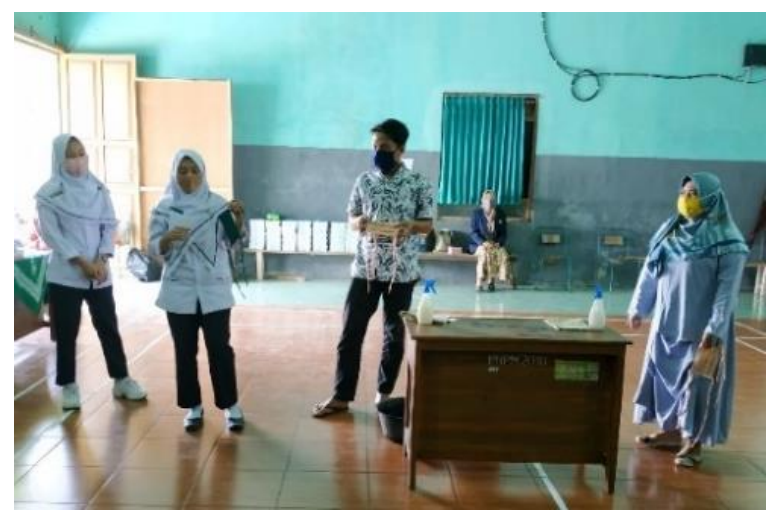

Gambar 3. Praktik Pemakaian Masker yang Benar

Tingkat pengetahuan tentang covid-19 meliputi pengertian, kelompok rentan, tanda gejala, cara penularan serta pencegahan penularannya. Sejumlah 23 orang kader posyandu mengalami peningkatan tingkat pengetahuan, 4 orang tetap dan hanya 3 orang yang mengalami penurunan tingkat 
pengetahuan. Secara ketrampilan kader mampu melakukan pengukuran suhu, cara mencuci tangan dan pemakaian masker yang benar, cara membuat larutan desinfektan dan melakukan proses desinfeksi untuk ruangan maupun perlengkapan rumah misalnya meja kursi (gambar 3).

Duta Covid-19 juga dilatih dalam melakukan pendidikan kesehatan kepada masyarakat sehubungan dengan covid-19. Duta Covid-19 diharapkan dapat melakukan transfer of knowledge kepada masyarakat tentang Covid-19 dengan pemahaman yang benar. Hal ini sesuai dengan kegiatan pengabdian masyarakat (Sitohang, Nasution and Adella, 2018) yang menyatakan bahwa ada pengaruh kader kesehatan reproduksi remaja terhadap sikap siswa, apabila sikap remaja terhadap perilaku seksual baik maka diharapkan remaja juga berperilaku seksual yang baik pula dan remaja diharapkan lebih bertanggung jawab terhadap kesehatan reproduksinya. Berdasarkan hasil penelitian tersebut, apabila Duta Covid-19 memberikan pendidikan kesehatan kepada masyarakat khususnya remaja maka dapat merubah perilaku masyarakat sesuai kondisi new normal saat ini.

\section{Posyandu Remaja "Cerdik"}

Posyandu remaja merupakan salah satu cara atau upaya tenaga kesehatan untuk menjemput bola dalam melayani remaja. Keberadaan posyandu remaja diharapkan dapat meningkatkan cakupan layanan terhadap remaja yang telah ada difasilitasi pelayanan kesehatan/ puskesmas (Yulika, 2019). Keberadaan posyandu remaja merupakan solusi yang dapat ditawarkan dimasyarakat. Sehingga dengan adanya posyandu remaja di tingkat pedukuhan dapat meningkatkan kesejahteraan serta kesehatan reproduksi remaja (Putri and Rosida, 2017)

Pelayanan kesehatan remaja di Posyandu adalah pelayanan kesehatan yang peduli remaja, mencakup upaya promotif dan preventif, meliputi : Program Ketrampilan Hidup Sehat (PKHS), kesehatan reproduksi remaja, kesehatan jiwa dan pencegahan penyalahgunaan Napza, gizi, aktifitas fisik, pencegahan Penyakit Tidak Menular (PTM) dan pencegahan kekerasan pada remaja (Kementerian Kesehatan Republik Indonesia, 2018). Kegiatan posyandu remaja diupayakan untuk mengatasi permasalahan remaja. Permasalahan yang terjadi pada remaja antara lain anemia pada remaja, kenakalan remaja, susah berkonsentrasi, kurang percaya diri, penyalahgunaan obat dan narkotika,
merokok.(Wahyuntari and Ismarwati, 2020).

Kegiatan posyandu remaja "Cerdik" desa Bojong kecamatan Mungkid kabupaten Magelang direncanakan untuk dilaksanakan dua kali dalam sebulan yaitu minggu kedua dan ketiga. Pada minggu kedua kegiatan dilaksanakan untuk wilayah desa Bojong atas yang meliputi 7 dusun, dan pada minggu ketiga dilaksanakan untuk wilayah desa Bojong bawah sebanyak 6 dusun. Tempat pelaksanaan kegiatan di PKD Desa Bojong, alasan pemilihan tempat ini karena rumah tidak digunakan oleh bidan dan berada di pinggir jalan desa sehingga aksesnya mudah. Dengan adanya posyandu remaja maka remaja dapat dengan mudah mengakses layanan kesehatan dan informasi kesehatan lainnya (Ertiana et al., 2010)

Sebagai persiapan untuk pelaksanaan kegiatan telah diberikan hibah alat pelayanan posyandu berupa timbangan berat badan, pengukur tinggi badan, tensimeter dan stetoskop, termometer infrared, metline, pita LILA. Suatu kegiatan tanpa dokumentasi atau administrasi yang baik maka dapat dikatakan sebagai suatu usaha yang tanpa arah dan tujuan. Sehingga tim pengabdian masyarakat juga menghibahkan buku-buku kegiatan yang meliputi buku inventaris, buku kegiatan posyandu, buku register remaja, buku rencana kegiatan, buku rujukan posyandu remaja, buku tamu, buku daftar hadir konselor, buku daftar hadir pengurus dan buku kas umum. Kader mampu melakukan melakukan dokumentasi pencatatan dan pelaporan kegiatan posyandu.

Upaya untuk menunjang kegiatan pengabdian masyarakat dan meningkatkan pengetahuan bagi kader serta remaja pada umumnya maka dihibahkan pula alat permainan Monopoli Triad KRR, alat permainan Ular Tangga Genre Kit, Modul Posyandu Remaja, Modul Covid-19 (gambar 7) dan Buku pendidik sebaya persiapan kehamilan sehat sejak masa remaja. Alat permainan Monopoli Triad KRR dan Buku pendidik sebaya persiapan kehamilan sehat sejak masa remaja merupakan produk hasil penelitian dari anggota tim pengabdian masyarakat.

Pemilihan alat permainan sebagai media penyampaian materi pada kegiatan pengabdian masyarakat ini sesuai hasil penelitian (Rofi'ah and Widatiningsih, 2020) yang menyatakan bahwa untuk menghindari kejenuhan saat pembekalan pra nikah maka sebaiknya dilakukan dengan metode inovatif salah satunya permainan. Demikian pula dengan buku sebagai suatu media yang cukup mendukung dalam 
bimbingan.

Desain Buku pendidik sebaya persiapan kehamilan sehat sejak masa remaja disusun menggunakan desain yang menarik dan dengan bahasa komunikatif sesuai jiwa remaja sebagai buku pegangan bagi kader posyandu remaja untuk membantu mempersiapkan kehamilan sehat sejak masa remaja (gambar 4). Media modul kesehatan reproduksi remaja agar dapat membantu meningkatkan pengetahuan maupun sikap remaja, yang pada akhirnya dapat merubah perilaku remaja khususnya tentang kesehatan reproduksi dalam mempersiapkan kehamilan sehat (Rofi'ah and Widatiningsih, 2021). Adapun Modul Posyandu Remaja dan Modul Covid-19 merupakan produk yang ditujukan khusus untuk kegiatan pengabdian masyarakat ini. Keempat media penunjang kegiatan pengabdian masyarakat ini telah mendapatkan sertifikat hak cipta dari Kemenkumham tahun 2020.

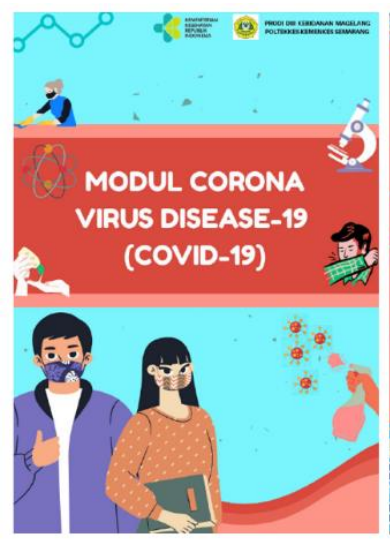

Gambar

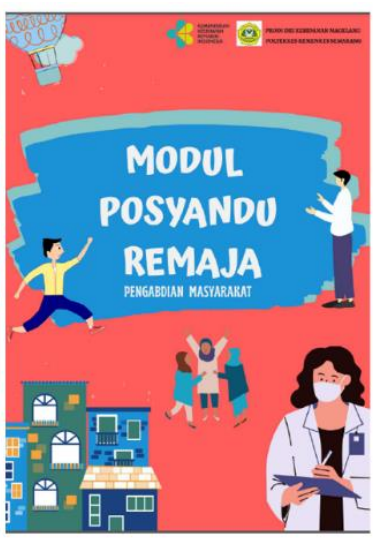

Pendukung Kegiatan Pengabdian Masyarakat

\section{Mitra PUI P2PTM Poltekkes Kemenkes Semarang dan Pemerintah Desa Bojong "Desa Sehat Remaja Bebas Anemia Defisiensi Fe" \\ Politeknik Kesehatan Kementerian}

Kesehatan Semarang sebagai salah satu Institusi Pendidikan Vokasi Kesehatan berkomitmen untuk bersinergi bersama dan berkontribusi untuk mengambil bagian dalam upaya menyelesaikan masalah PTM. Pusat unggulan pencegahan dan pengendalian PTM akan melibatkan berbagai disiplin ilmu dan profesi kesehatan di lingkungan Poltekkes Kemenkes Semarang, sehingga terjalin kerjasama multi disiplin untuk menyelesaikan permasalahan yang masih menjadi fokus perhatian pemerintah sampai saat ini terkait Penyakit Tidak Menular yaitu penyakit cardiovaskuler, Diabetes Melitus, Stroke, Hipertensi, dan lain-lain. Pusat Unggulan Pencegahan dan Pengendalian Penyakit Tidak
Menular (PTM) Poltekkes Kemenkes Semarang berkomitmen untuk meningkatkan derajat kesehatan masyarakat melalui upaya promotif, preventif, kuratif terbatas dan rehabilitatif yang inovatif (Poltekkes Kemenkes Semarang, 2020).

Prodi Kebidanan sebagai bagian dari Poltekkes Kemenkes Semarang berusaha berkontribusi mendukung program yang diselenggarakan oleh Institusi Poltekkes Kemenkes Semarang. Kegiatan posyandu "Cerdik" berupaya untuk melakukan kegiatan untuk mendukung pencegahan penyakit tidak menular pada remaja salah satunya dengan KIE pencegahan masalah gizi remaja yaitu anemia serta pemberian tablet tambah darah (Kementerian Kesehatan Republik Indonesia, 2018). Pengetahuan remaja tentang anemia masih kurang seperti yang disampaikan oleh (Angelina et al., 2020) yang menyatakan bahwa gambaran pengetahuan siswi kelas XI tentang dampak anemia terhadap kesehatan reproduksi di SMA negeri 6 medan tahun 2019 Mayoritas responden berpengetahuan kurang sebanyak 16 orang (54\%).

Anemia defisiensi besi pada remaja masih menjadi masalah. Jika tidak diobati, itu akan berlanjut sampai dewasa dan berkontribusi besar terhadap angka kematian ibu, kelahiran prematur, dan bayi dengan berat lahir rendah. aktor yang terkait dengan kejadian anemia defisiensi besi pada remaja putri di perkotaan adalah asupan protein dan asupan zat besi (Sari, Dardjito and Anandari, 2016). Hal ini dapat dikarenakan pola makan remaja yang menyukai junk food dan fast food. Khususnya pada remaja putri, hal seperti ini rentan mengalami defisiensi zat gizi.

Salah satu faktor penyebabnya adalah karena faktor pengetahuan. Pengetahuan anemia yang kurang akan mempengaruhi pemilihan makanan yang bersifat membantu dan menghambat penyerapan besi dalam tubuh. Semakin sering mengonsumsi makanan yang menghambat (inhibitor) Fe maka akan mempengaruhi status besi dalam tubuh seseorang. Status besi dalam tubuh yang cukup pada saat awal masa remaja dapat mengurangi kecepatan pertumbuhan remaja, karena defisiensi besi dapat mengurangi selera makan, asupan makan dan energi (Simanungkalit and Simarmata, 2019).

Berdasarkan hal tersebut, maka dipandang perlu untuk melakukan pendampingan bagi remaja melalui Desa Mitra PUI P2PTM Poltekkes Kemenkes Semarang dan Pemerintah Desa Bojong "Desa Sehat Remaja Bebas Anemia Defisiensi Fe". Diharapkan dengan kegiatan ini 
maka remaja desa Bojong akan memiliki pengetahuan yang baik tentang anemia sehingga berperilaku yang benar untuk mencegah anemia sejak masa remaja dalam mempersiapkan kehamilan sehat untuk mencetak generasi bangsa yang berkualitas.

\section{Simpulan dan Saran}

Pelaksanaan kegiatan pengabdian masyarakat "Inisiasi Posyandu Remaja melalui Pembentukan Duta Covid-19" di desa Bojong Kecamatan Mungkid kabupaten Magelang mampu memberdayakan remaja sebagai kader posyandu remaja sekaligus Duta Covid-19 sehingga ikut bertanggungjawab terhadap kesehatan reproduksi remaja dan kesehatan secara umum pada masa pandemi. Posyandu remaja telah terbentuk dan siap melakukan kegiatan pelayanan 2 kali sebulan untuk meningkatkan kualitas kesehatan remaja. Untuk mendukung peningkatan kualitas remaja tersebut juga telah terjalin kerjasama antara Poltekkes Kemenkes Semarang dan Pemerintah Desa Bojong sebagai Mitra PUI P2PTM untuk mewujudkan Desa Bojong sebagai "Desa Sehat Remaja, Bebas Anemia Defisiensi Fe". Disarankan agar Bidan Desa maupun Puskesmas serta aparat desa dan PLKB Desa Bojong yang terlibat aktif dalam pemberdayaan remaja agar terus membina kader posyandu remaja serta memantau kegiatan posyandu remaja "Cerdik" Desa Bojong Kecamatan Mungkid sehingga dapat secara terus menerus dan semakin banyak dan bermanfaat untuk masyarakat

\section{Ucapan Terima Kasih}

Terima kasih kami ucapkan kepada: (1) Pusat Penelitian dan Pengabdian Masyarakat atas kesempatan dan dukungan dana dengan skema Pengabdian Masyarakat tahun 2020 serta Penugasan Tim Pengabdi. (2) Kepala Desa Bojong kecamatan Mungkid kabupaten Magelang beserta staf pemerintah Desa dan masyarakat khususnya remaja yang telah berpartisipasi aktif dalam kegiatan pengabdian masyarakat; (3) Kepala Puskesmas Mungkid, Bidan Desa Bojong dan PLKB Desa Bojong atas kerjasamanya baik dalam pemberian dukungan dan monitoring Posyandu Remaja

\section{Daftar Pustaka}

Angelina, C. et al. (2020) 'Pengetahuan Siswi Kelas XI tentang Dampak Anemia terhadap Kesehatan Reproduksi',
Jurnal Keperawatan Priority, 3(1), p. 99. doi: 10.34012/jukep.v3i1.856.

Ertiana, D. et al. (2010) 'Program Peningkatan Kesehatan Remaja Melalui Posyandu Remaja', Journal of Community Engagement and Employment, 2(1), pp. 2-8.

Ismarwati and Ernawati, D. (2016) 'IbM Posyandu Remaja', in RAKERNAS AIPKEMA 2016 "Temu Ilmiah Hasil Penelitian dan Pengabdian Masyarakat". Semarang, pp. 198-204.

Kementerian Kesehatan Republik Indonesia (2018) Petunjuk Teknis Penyelenggaraan Posyandu Remaja. Jakarta: Kementerian Kesehatan Republik Indonesia. Available at: http://kesga.kemkes.go.id/images/ pedoman/Petunjuk Teknis Posyandu Remaja.pdf.

Kementerian Kesehatan Republik Indonesia (2020) 'Pedoman Pemberdayaan Masyarakat dalam Pencegahan Covid-19 di RT/RW/Desa'. Jakarta: Kementerian Dalam Negeri Republik Indonesia.

Menkes RI (2014) 'Peraturan Menteri Kesehatan Republik Indonesia No.25 Tahun 2014'. Jakarta: Kementerian Kesehatan Republik Indonesia. Available at: http://kesga.kemkes.go.id/images/ pedoman/PMK No. 25 ttg Upaya Kesehatan Anak.pdf.

Poltekkes Kemenkes Semarang (2020) PUI P2PTM Politeknik Kesehatan Kementerian Kesehatan Semarang, Web PUI P2-PTM. Available at: http://poltekkessmg.ac.id/pui/?page_id=25

(Accessed: 19 December 2020).

Putri, I. M. and Rosida, L. (2017) ‘Pelatihan Kader Pembentukan Posyandu Remaja di Dususn Ngentak Bangunjiwo Kasihan Bantul Yogyakarta', in Seminar Nasional Publikasi Hasil-Hasil Penelitian dan pengabdian Masyarakat 'Implementasi Penelitian dan Pengabdian Masyarakat untuk Peningkatan Kekayaan Intelektual'. Semarang: Universitas Muhammadiyah Semarang, pp. 528-533. 
Rofi'ah, S. and Widatiningsih, S. (2020) 'Healthy Pregnancy Preparation through Premarital Guidance Model on Prospective Brides', International Journal Of Pharmaceutical Research, 12(1). Available at: http:/ / www.ijpronline.com/ViewAr ticleDetail.aspx?ID=17468.

Rofi'ah, S. and Widatiningsih, S. (2021) 'Development of Adolescent Reproductive Health Module Media', Jurnal Kebidanan, 11(2), pp. 126-135. Available at: https://ejournal.poltekkessmg.ac.id/ojs/index.php/jurkeb/arti cle/view/6635.

Sari, H. P., Dardjito, E. and Anandari, D. (2016) 'Anemia Gizi Besi pada Remaja Putri di Wilayah Kabupaten Banyumas', Jurnal Kesmas Indonesia, 8(1), pp. 16-31.

Simanungkalit, S. F. and Simarmata, O. S. (2019) 'Pengetahuan dan Perilaku Konsumsi Remaja Putri yang Berhubungan dengan Status Anemia', Buletin Penelitian Kesehatan, 7(3), pp. 175-182.

Sitohang, N. A., Nasution, D. L. and Adella, C. A. (2018) 'Pemberdayaan Siswa sebagai Kader Kesehatan dalam Program Edukasi Kesehatan Reproduksi Remaja Di SMP Swasta Medan', Jurnal
Riset Hesti Medan, 3(2), p. 27. doi: 10.34008/jurhesti.v3i2.40.

Sukini, T., Widatiningsih, S. and Rofi' ah, S. (2017) Praktik Manajemen Kebersihan Menstruasi di SMA Negeri se-Kota Magelang. Magelang. doi: 10.1017/CBO9781107415324.004.

Susanti, S., Apriasih, H. and Danefy, T. (2020) 'Pemberdayaan Masyarakat melalui Pelatihan Kader Posyandu Remaja Uswatun Hasanah Desa Cikunir', ABDIMAS: Jurnal Pengabdian Masyarakat, 3(2), pp. 279-284. doi: 10.35568/abdimas.v3i2.579.

Wahyuntari, E. and Ismarwati, I. (2020) 'Pembentukan Kader Kesehatan Posyandu Remaja Bokoharjo Prambanan', Jurnal Pengabdian Masyarakat (AIPKEMA), 1(1), pp. 1418. Available at: http://www.ejournalaipkema.or.id/aipkema/index.php/j pma/article/view/65.

Yulika, D. (2019) Posyandu Remaja 'FRESH' Posyendu Remaja Pertama di Kepri, PRIMETIMES.id. Available at: https://primetimes.id/2019/04/22/ posyandu-remaja-fresh-posyanduremaja-pertama-di-kepri/ (Accessed: 3 May 2020). 